\title{
LANDSCAPES OF LOST ENERGY: COUNTERFACTUAL GEOGRAPHICAL IMAGINARY FOR A MORE SUStAINABLE SOCIETY
}

\author{
Dan van der HORST
}

\begin{abstract}
The quest for sustainable energy, one of the greatest challenges of the 21st century, calls for more input from academics than 'simply' producing good science. Geographical imaginations are as old as storytelling and mapmaking, but this essay is neither about 'long ago and far away', nor about utopian energy futures. This is a call to geographers to engage with 'alternative present' energy scenarios, using the full range of analytical and discursive tools at our disposal. Drawing on a diverse tradition of imagined spaces and the awareness of absences (material, relational or otherwise), geographers should be able to contribute to the quest for a more sustainable society by assessing, envisaging, and communicating a counterfactual 'here and now', based on good practices existing right now, but not (yet) right here. We need to understand how much more sustainable our bit of the planet would be if we could just, environmentally speaking, 'keep up' with the best of our neighbours. This counterfactual present should be seen as neither radical nor utopian, because it only assumes the historic adoption of best practices which we now know to be feasible and successful. And if this alternative current scenario looks radically different from the 'real' state we are in, then this goes to show how radically unsustainable our business-as-usual approach has been.
\end{abstract}

\section{Shrnutí}

\section{Krajiny ztracené energie: kontrafaktické geografické imaginárno pro udržitelnější společnost}

Hledání udržitelné energie, které je jednou z největšich výzev 21. století, si žádá od vědců více než „jen“" produkovat kvalitní vědu. Geografické imaginace jsou stejně staré jako vyprávění př́běhủ a tvorba map, ale tato esej není ani o tom, co bylo „dávno a daleko" ani o utopické energetickébudoucnosti. Je to výzva geografưm zabývat se současnými alternativními energetickými scénáři s využitím všech dostupných analytických a diskurzivních nástrojů. Čerpáním z pestré tradice imaginativních prostorů a uvědoměním si nedostatků (materiálních, relačních či jiných) by geografové měly být schopni přispět k hledání udržitelnějši společnosti pomocí zkoumání, hodnocení a komunikování kontrafaktického „tady a ted", založeného na príkladech dobré praxe, které existuji právě ted', ale (ještě) ne tady. Potřebujeme porozumět tomu, jak by mohl být náš kus planety udržitelnější, pokud bychom mohli - ve smyslu environmentálním - „držet krok“ s těmi nejlepšimi z našich sousedů. Tato kontrafaktická př́tomnost by neměla být nahližena jako radikální ani utopická, nebot' pouze předpokládá historické prijetí nejlepšich př́kladi̊ praxe, o kterých nyní víme, že jsou proveditelné a úspěšné. A pokud se tento alternativní současný scénář zdá být radikálně odlišný od „skutečného“ stavu, ve kterém se nacházíme, potom to ukazuje, jak radikálně neudržitelný náš př́stup „dělat věci jak obvykle“je.

Keywords: counterfactual, imagery, imagination, energy literacy

\section{Introduction}

NASA's famous 'Earth at Night' picture shows the cities of the world shining like diamonds on a dark background map that only distinguishes land and sea. This picture is obtained from 'hard' satellite data, and yet it is a carefully manipulated mixture of empirical reality and visual imagination; the cloud cover has been removed, the planet is projected in two dimensions and the time zones are collapsed into a single night time. Geographers have long been obsessed by terrae incognitae (e.g. Wright, 1947) and 'seeing' in the night and seeing earth from space are two prime examples of Geographical Imagination. NASA's manipulated map may have largely been created for aesthetic purposes, but it has moral connotations as well; is it encouraging us to see the beauty in light pollution? Is it stereotyping Africa as the 'dark continent'? NASA's map could be interpreted as an indication of energy wastage in affluent countries and the shortage of basic lighting services in poorer parts of the world.
The broad scientific consensus about anthropogenic climate change is now a generation old. Students graduating this year with a Ph.D. in climate science were not even born when the problem was already identified and widely agreed upon by those with the appropriate disciplinary expertise. It is thus not the lack of science which has caused the lack of action. But that does not mean to say that academics cannot do more to bring the need, urgency and options for adaptation and mitigation closer to the attention of various sections of society. There are very many studies of how much we need to do, how far off target we are, etc. but there is scope to do more than 'just' producing those estimates. For that matter, there is scope for doing more than 'just' theorising human-nature relations or critiquing capitalist accumulation. With 'Earth at Night', NASA's remote sensing experts demonstrated that they can combine their expertise with their imagination, and this paper calls for geographers to do the same. In previous publications 
(Nadai, van der Horst 2010a; 2010b) we have called for more research on the landscape/energy nexus. This paper adds a new and distinct category of academic activity to that research agenda.

The aim of this paper is to promote critical engagement with 'our' energy system by imagining and examining the geography of 'lost energy'. The laws of physics stipulate that energy cannot be lost, but my framing of 'loss' in this paper is explicitly anthropocentric and normative; I want to draw attention to the energy that we failed to capture or utilise for our benefit. Although there are still some shameful cases of wastage of fossil fuels in the $21^{\text {st }}$ century (e.g. continued gas flaring in the Niger delta; the Deepwater Horizon oil spill in the Gulf of Mexico), on the supply side the attention should go towards renewable energy. Fossil fuels are replenished over (a very long) time, whereas renewable energy sources like wind and waves are replenished over space. It would therefore require a more temporal strategy to deal sustainably with fossil fuels, and a more spatial strategy to deal sustainably with renewables. The energy flux of the wind and sunshine and flowing water that is not captured now is a lost resource, an opportunity that is gone forever. How can we justify such lost opportunities in a world threatened by anthropogenic climate change?

On the demand side, we can ask ourselves many critical questions about the amount of societal good that our energy consumption patterns have delivered. It is ironic that our conspicuous consumption of lighting services has created such externalities that we depend on NASA's eyes in the sky (satellites) and the artistic license of NASA's remote sensing experts, to internalise this energy wastage through the means of a visual aesthetic, bringing the light that we have carelessly spilled into space, back to earth for cultural consumption. This paper does not seek to deliver a dispassionate and novel contribution to knowledge. It is a call for imaginative and creative engagement with the energy/ society nexus, highlighting some important contributions that geographers can make.

In general society is somewhat conservative when it comes to challenging the status quo, changing the system or upstaging the incumbent. This systemic bias in favour of the devil we know means that there is a need for creative approaches to help people think outside their familiar box. In this context, imagining is a necessary skill rather than a frivolous activity. The low carbon energy transition requires radical and systemic step changes rather than marginal and gradual alterations if we are to truly deal with the multiple energy challenges we face: the era of cheap fossil fuels seemed to have come to an end in 2008; most coal-fired and nuclear power plants across Europe are decades old and need to be either closed down or expensively refurbished to extend their life a little longer; there are concerns about the increased dependency on Russian gas or fossil fuel from the turbulent Middle East; and last but not least, a number of countries are formally committed to very radical cuts in greenhouse gas emissions. Short term, myopic business-as-usual approaches will block this transition, whereas imagination may aid it, by inspiring or by showing the way. And there is a lot of space for imagination and imagery in the geography of energy.

\section{Energy, geography and absence}

The relationship between energy and geography is both intimate and complex. Cheap and abundant energy is the nemesis of geographical constraints, helping (the more energy affluent amongst) humans to conquer space, overcome climate and 'globalise' our lives, economy and society. However, our $21^{\text {st }}$ century energy dilemma is how to flourish as a society without using quite so much (conventional) energy. Using less energy means living with more geography; smart and selective (partial) relocalisation; finding better ways to live with nature. Before we can decide how to adapt, we need to understand, and agree on, the extent to which we are currently not doing it right. This question of the legibility of the sustainability implications of our behaviour comprises a challenge to thinkers, researchers and educators alike. This legibility may be pursued through theory and empirics, through lab, class and fieldwork. Images are widely used as a tool for legibility, from microscopic pictures of pollutants, to satellite images of algae bloom or deforestation. But there are ecological concerns that cannot be easily communicated by showing things as they are. Rachel Carson's (1962) influential book, Silent Spring, provides a powerful example; it was the absence of a sound, bird song, which she uses to make legible the nefarious impacts of pesticides on wildlife. More recently, several authors have referred to the absence of visual clues as a form of silence, including the deconstruction of geographical maps by revealing the counter narratives of subaltern groups (e.g. Vermeylen et al., 2012). Drawing attention to silence or absence can be an evocative tool to enhance our understanding of the unsustainability of certain socio-ecological conditions. The very same can be said of socio-technical conditions, as is evidenced for example by NGO efforts to assess and identify (for further protection) areas where the audio and visual impacts from the industrial age are relatively scarce, e.g. tranquillity mapping (Jackson et al., 2008) and 'Dark Sky Parks' designations (www.darksky.org), the latter providing a counterpoint to NASA's 'Earth at Night' imagery.

As geographers, there are many ways in which we can use imagination and imagery to increase the legibility of that which can be, but is not, here and now. One of our original disciplinary strengths is the making, studying and manipulating geographical maps. As an obvious early step in this quest, map-minded geographers could set out to examine how various kinds of energy-related maps can inform us of our existing energy practices and help us to think or imagine geographically better ways to configure and utilise our energy systems. This is not 'mapping the gap' of existing bio-physical supply of energy or socio-political demand of energy services or the mapping of utopian future scenarios, but the mapping of a 'lost present', i.e. the energy landscape we would be inhabiting now if we had been early adopters and adaptors in the transition to a low carbon society. We should seek to expose the counterfactual of insufficient environmental policies and actions within a landscape or region. In doing so, we would make a contribution to an already welldeveloped tradition of geographical imaginations, which may take up 'a location somewhere between the domains of the factual and fictional, the subjective and objective, the real and representational' (Daniels, 2011, p. 183). Moreover, imagining other and better energy worlds would constitute a rare effort to create something akin to 'spaces of hope' (Harvey, 2000, p. 33): "What partially separates us human architects from bees, however, is that we are now obliged (by our own achievements) to work out in the imagination as well as through discursive debates our individual and collective responsibilities not only to ourselves and to each other but also to all those other 'others' that comprise what we usually refer to as 'external' nature ('external,' that is, to 
us)." In the context of anthropogenic climate change, these 'others' include existing climate vulnerable communities, future generations and those who are doing more 'their bit' in climate change mitigation than we are.

It is not possible within the word limits of this essay to do justice to existing literature on geographical imaginations and geographical imagery. Moreover, there has been a recent upsurge in papers (mainly by geographers) on energy-related imaginaries of the state, private sector investors and NGOs (Perreault and Valdivia, 2010; Levidov and Papaioannou, 2010; Boamah, 2014; Shim, 2014). The Dictionary of Human Geography provides a useful potted summary, indicating not only the psychoanalytical origin of imagery as a concept, but also the 'co-mingling of culture and nature' implicit in the more landscape-oriented writings on geographical imagination. The title of this piece is consistent with the description in The Dictionary of geographical imagery as 'a taken-for-granted spatial ordering of the world' which human geography should seek to disclose and examine its 'often unacknowledged effects', but also with the modern take on geography as a discourse, whereby human geography is construed as 'a site where images of the city and space more generally are set up as reality' (Gregory et al., 2009; pages 282 and 284 respectively). Hence I propose that there is scope for a counterfactual geographical imagery as a discourse which challenges this 'taken-for-granted spatial ordering', by projecting a world that is remarkable for the absence of these unacknowledged effects ${ }^{1}$.

The idea of a counterfactual is fully embedded in the practices and tools of policy appraisal and the accounting of externalities such as carbon emissions. For those types of uses, the counterfactual is the scenario of what would have happened in the absence of a particular policy or intervention: (agreeing on) the counterfactual is a prerequisite for determining how additional the project or policy is. For those purposes, the counterfactual is often established through a discursive approach that pays detailed attention to political, socio-technical and biophysical context, yielding a narrative that contains both qualitative and quantitative aspects. Whilst this kind of counterfactual has been of much applied academic interest (e.g. Begg and van der Horst, 2004) and subsequent critical interest (especially in the context of the commodification of nature debate, e.g. Lancing, 2010), this is not the kind of counterfactual that is of primary interest for this paper. More relevant, conceptually, is the literary tradition of alternative histories. Indeed, that tradition has given historians the inspiration to examine the idea of the counterfactual (see Tucker, 1999), which in turn has inspired historical geographers, culminating in a special issue in the Journal of Historical Geography (Gilbert and Lambert, 2010). That special issue actually contains a paper that is explicitly about counterfactual energy landscapes. In 'Landscapes without the car', Pooley (2010) examines a counterfactual historical geography of what Britain would look like if car ownership had been curtailed in the $20^{\text {th }}$ century. As an exemplar of scholarship on the counterfactual geographies of energy, Pooley's paper opens the door to many similar studies (of other countries, or other energy technologies), potentially providing a bridge for a new type of engagement with the energy transitions literature, some of which is also strongly historical in nature (e.g. Turnheim and Geels, 2013). For the purpose of this paper, however, I am focusing my attention specifically on constructing a counterfactual geography of energy that asks less of what has happened in this location in the past, and more of what is happening in other places right now. The rationale for this focus is explored below.

\section{Energy literacy}

The history of human civilisations can be told through the energy lens (e.g. Pimentel and Pimentel, 1979; Smil, 1994), and energy also features strongly in discussions about the future of society. High energy prices and the fear of anthropogenic climate change have led to a quest for a more sustainable society in terms of energy and resource use, often phrased through narratives of 'transitions', 'escaping the lock-in', 'green innovations', and 'de-carbonising our economy'. Many of the technical, economic, institutional and social barriers to changing our energy use are linked to the peculiar physical characteristics and spatial configurations of our energy systems. Oil, gas and electricity are just about the only commodities (knowledge and data transfer not included) that are traded through grids, with pipes and wires running for thousands of kilometres, across national boundaries, along the sea-floor, over or through mountain ranges to connect multiple locations of production with (in the case of gas and electricity) a large number of dispersed consumers. Especially electricity is a commodity with unique space-time characteristics. It is produced in one location and instantaneously consumed in a multitude of other locations, i.e. it is (to simplify it a bit) a commodity that travels in space but not in time. Gas and electricity are more or less intangible and are mainly represented by the fixed physical infrastructure that enables their transport and utilisation. Oil, on the other hand, is a commodity that is largely used for transport, i.e. to observe its use is to observe the geographical movement of cars, trains and planes and the people and goods within them. We have not even touched upon the geopolitics of energy, and it is already very clear that our energy system cannot be understood in isolation from its geographical and political context.

On the supply side, the visibility of extractive technologies to local communities has often (simplistically) been portrayed as a fundamental reason for local opposition (e.g. van der Horst, 2007). On the demand side the very opposite can be found: energy has been largely 'invisible' in the consumptive choices of our daily life. There has been research on the level of 'energy literacy', especially of young people (e.g. Dewaters and Powers, 2011), and on the available methods to 're-materialise' energy use through improved monitoring and labelling (Burgess and Nye, 2008) and the use of smart energy monitors (Hargreaves et al., 2010). Whether the focus is on the indoor geographies of 'smart' homes, on the socio-political landscape of the auto-motive age, or on local, national and international level of energy use, this paper fits very much within this need to visualise and communicate energy issues as part of the agenda to move to a cleaner and more efficient energy system. In the same vein (if not necessarily with quite the same spiritual fervour) that the concept of 'earth literacy' is promoted by some educators (see www.earthliteracies. org), we must acknowledge the educational undertones of

\footnotetext{
${ }^{1}$ For the sake of clarity, it is worth noting that my interest in counterfactual geography is very different from the recent work by Fall (2013), who explores the counterfactual of the development of geography as a discipline.
} 
the term 'energy literacy'. I would argue that there is a moral imperative for energy researchers to draw attention to poor energy policies and practices. Whilst we have not been elected to make policies, as academic citizens and knowledge workers for the common good who are largely sustained by general taxation and tuition fees, we have a moral obligation to speak truth ${ }^{2}$ to power by providing critical reflections on existing policies and societal trends and the possible long-term repercussions of these. Whilst we are rarely in the position to (effectively) tell policy makers what we think they should be doing, we certainly have the capability and the right to inform society what 'now' would look like if different (and better) decisions had been made in the past. Counter-narratives play a central role in the societal remit of Human Geography as a discipline that is able and willing to critique incumbent regimes for power structures that reproduce inequality, or for institutional thickness that favours unsustainable business-as-usual practices. Counterfactual geographical imagery of more sustainable energy landscapes would add another strand to this tradition of counter-narratives.

\section{Possible examples}

So how can we go about imagining and making legible the more sustainable energy landscape that could have been, now? In a paper that calls for imagination, it would be rather inappropriate to offer prescription. Different sections of our discipline may be able to draw on entirely different methods and paradigms here, from map overlays and probabilistic modelling to the sensuous and performative. As a starting suggestion, and drawing on my own areas of relative expertise, I can envisage at least four aspects of energy use that lend themselves for counterfactual geographical imagining.

First we should seek the avoidance of zero and negative returns on energy consumption. Zero returns on energy consumption are common in everyday life; e.g. boiling more water than we need, leaving the lights or the heating on in empty rooms. This is the domain of where smart metering and feedback displays, the labelling of energy appliances and inbuilt and pre-programmed sensors (e.g. motion detectors in light switches) rub against human behaviour, habits and practices. At the level of individuals, households and the work place, there is now a substantial amount of social science research into awareness of energy consumption, energy practices and energy literacy. There are publications, animations, pictures and testimonials of 'the house of the future' and of ecologically-minded citizens cutting down their energy bills whilst still appearing healthy and happy. Some cars equipped with a voluntary setting for more fuelefficient driving, provide the driver with feedback on the amount of fossil fuel saved, or the extra miles the car can go as a result of improved fuel efficiency. This is counterfactual baseline that shows how much more efficient the actual car is, in comparison to some sector average. It provides the driver with a positive message that $\mathrm{s} / \mathrm{he}$ is saving fuel and money by driving a more fuel efficient car. The counterfactual I'm focusing on in this paper is equivalent to 'normal' cars having a sign on their dashboard saying how much fuel and money the driver would have saved if s/ he had driven an energy efficient car instead. It would thus question how 'normal' the business-as-usual cars are.
What is perhaps less well-researched, is the extent to which we understand that energy consumption can have negative returns. Examples in the transport sector are an obvious start: would we have the same levels of 'road rage', 'food deserts' or obesity if our urban transport system and urban planning would have prioritised walking, cycling and public transport, thus opposing the hegemony of the private car and the associated super-concentration of food sales in huge supermarkets with huge car parks at the edge of town? Cycling in the Netherlands or car-free Venice, are well-known better practice examples, but they are often filed away as historic anomalies or cultural exceptionalism. How can we imagine and visualise a more local situation where these negative effects of excessive private mobility have been challenged? Some imaginative approaches have appeared over the years, e.g. car-free days in inner cities, organised bike rides, earth hour. These typically have a performative and even a festive character, and do not take place each and every day. It is not clear to what extent they are now perceived as a normalised tradition for some ('progressive') sections of society (i.e. embraced as they are) or seen as a continued political rallying call for an overhaul of carfriendly urban governance.

There is certainly scope for more geographical imaginations in this respect. In cities where cycling has long been neglected by planners and policy makers and largely abandoned by the public, the appearance of new maps with cycling routes are a great example of geographical analysis and imagination coming together to encourage local action for cleaner, healthier and more socially-inclusive transport. These maps often do not so much indicate what cyclists do at the moment, but what they could do. These maps feed the imagination and provide a prescription. In doing so, they encourage change to happen, i.e. for more people to cycle and for local authorities to plan more and better for the needs of cyclists.

Secondly, we should query the efficient and effective use of energy generation and waste management technology. One particular example from the United Kingdom springs to mind. Despite having a climate which necessitates the heating of buildings for most of the year, and despite widespread and systemic problems of fuel poverty, thermoelectric power plants in the UK waste most of the energy they generate, because they only seek to utilise the electricity, not the heat. The scaling-up of space heating technology, from heating individual rooms to heating individual buildings to heating city blocks, was a logical development that has been pursued in the city centres of most cold countries since the first developments of steam district heating in New York in the 1880 s. Despite many early attempts by local councils to develop district heating in the UK (Russel, 1993), the UK has largely abandoned this technology, and its coal-fired and nuclear power stations are throwing out more energy into the atmosphere (in the form of steam) than they produce energy for the electricity grid. This very wasteful system is all the more painful to observe when the environmental justice literature shows us time and again that it is mainly the less wealthy who tend to live in the vicinity of power plants. An obvious example of geographical imagination would involve the identification of the areas surrounding the power plant which could be served by district heating from the plant, and

\footnotetext{
${ }^{2}$ I see the expression of 'speaking truth to power' in the context of Habermas' discourse ethics, which draws attention to the counterfactual conditions or presuppositions of un-coerced agreement. Within that context, academic truths are vital components of liberal democracy.
} 
the assessment of the number of people who could be lifted out of fuel poverty if the waste heat of the plant was provided to heat the homes of nearby residents.

A related example concerns the lack of energy recovery from waste. In many countries, this lowest step of the waste hierarchy (after reduce, reuse, recycle) has long been ignored politically, because it is a difficult sell to local residents. And yet some countries have strongly embraced waste-toenergy district heating plants (e.g. Austria, Denmark and Sweden), and also in countries that seemed to oppose them we can find exceptions (e.g. the city of Sheffield). Talking of imagination, what better example can we find than the award-winning waste-to-energy plant feeding Vienna's district heating system: designed by the artist and architect Hundertwasser, it is perhaps the city's most famous building and the most famous operational thermal power plant in the world. District heating linked to waste management can be valuable beyond the recovery of calories and the destruction of harmful bacteria and substances. It has the potential to address local pockets of fuel poverty and to connect people with their own waste production. Unlike the invisibility of energy flowing through electric networks, heat networks provide a more concrete material link between the home and the power plant and a tangible benefit of living near an operational power plant. There is thus scope for a geographical imagination in seeing and communicating not only how much waste we produce, but also how it has been dumped into unsightly and noxious landfills in urbanised regions, where land is scarce and energy is expensive.

Thirdly, we should draw attention to the biophysical underutilisation of locally-available resources. This is not merely a call for reproducing maps with estimates of wind potential or biomass yield. Many such resource mapping studies have been commissioned and carried out in the last twenty years. There is scope for geographical imagination in identifying specifically which areas have not been developed, and asking critical questions about why that is. Examples could include the assessment of the wind potential along all major motorways, harbours and industrial areas, as these are locations where few people live, noise levels are already significant, the disruption of traditional or highvalue landscapes has already been 'achieved' and potential near-by demand for energy and the opportunities for gridconnection are very high.

Further examples could include the opportunity cost of the full exclusion of wind farms from certain protected areas, such as protected landscapes, buffer zones around towns, or flight paths and military installations such as radar ranges. In the UK, national parks (which have their own planning powers) have not only consistently banned wind farm developments within their territory, but in some cases they have opposed the development of wind farms in the vicinity of the national park, thus extending their visual claim over the landscape far beyond their formal administrative remit. It could be argued that national parks should be run under a green agenda, which includes efforts to minimise and offset the emissions associated with the existence and functioning of the park. I would certainly not seek to argue that all national parks should be 'full' (whatever that might mean) of wind turbines, but I would welcome an assessment of (a) the amount of carbon emitted through cultural consumption of the amenities of the national park, by visitors and more economically-privileged residents alike (in the UK, property prices within national parks are considerably higher than those beyond the boundary), and (b) the amount of wind energy forgone by the nation because of the refusal of national parks to play host to this technology. Such a proposed assessment could open up imaginative debates about equity, tensions between local-global and short- and long-term nature conservation, the (changing) functions of national parks, and about possibilities for local off-setting of the carbon footprints of tourist hotspots.

Fourthly, we should consider the question of how policies perform. Ambitious targets may be unachievable due to weak support structures, and strong relative performance may be explained away by favourable conditions that have nothing to do with strong financial commitments or brave political decisions. For example, the UK was one of the very few western countries to achieve its Kyoto target, but this was not due to strong policies on renewables or energy conservation (the UK was a comparative laggard in both respects). Rather, it was an accidental by-product of privatisation, which resulted in a dash-to-gas (the cheapest technology). Furthermore, there is often a large discrepancy between the (loud) political and public debate about (say) renewable energy, and the (humble) actual size of the sector, in terms of KWh generated and in terms of money invested. This discrepancy is problematic because it can cause public impressions that much is being done and achieved, whereas the very opposite is true in terms of actual renewable energy production.

Rather than focusing on issues such as the level of public subsidies, or on ambitious targets set in a future that is far beyond a term in office, a geographical imagination of good energy policies should address the following sorts of questions: 'How much better would we perform if we were to do our fair share?'; 'How can we adopt and improve on the policies of those who are leading in this effort?'; and 'How can we work back from the energy future we want, to design and adopt the right policies today?'. A counterfactual geographical imagery of existing policies in the UK will show both failings and room for improvement. For example it might show all wind farm planning applications that were not granted permission, or it might create an interpretation on an annual basis of the legally binding 2050 UK government target to reduce carbon emissions by $80 \%$ of 1990 levels, and thus display by how much we have missed the target this year. This imaginary basically helps us to assess to what extent (other-wise bold-sounding) policies are actually delivering the goods.

Moreover, we could examine alternative policies altogether, from state-led and command-and-control to the far end of neo-liberal logic. Ideas could range from taxing real estate owners for heat waste or wind waste, to legalising wind- and water-squatting (right to install a mobile turbine on the land/in the water course of someone who is not harnessing that energy themselves), to selling the view by auction (so that local residents who do not like looking at wind farms, can chose to outbid a wind farm developer), to internalising carbon emissions in the cost of mortgages and car-leasing contracts, that in turn are used to fund off-setting projects within the local area.

\section{Conclusions}

This paper makes the case for a geographical imagination of a more sustainable here and now, more counterfactual in the 'here' than in the 'now'. I call for a visioning of better energy practices on the supply and demand sides, based not on some utopian ideals of society or scientific-economic 
arguments about the size and accessibility of energy resources, but on observations of existing good practices by some of this planet's more pioneering individuals, institutions or administrations. Rather than dismissing them as being far away in space and culture, our geographical imagination can help to reduce this othering, and portray our lives and our bit of the planet as if we had operated like them. This can help to bring us closer to those early adopters, challenge the lazy perception that this adoption accentuates their otherness and make us reflect on the strangeness of the situation in which nothing much was happening in our own bit of the planet, causing us to start lagging behind. I would argue that this alternative current scenario should be seen as neither radical nor utopian, because it only assumes the historic adoption of best practices which we now know to be achievable and workable. Looking at the mirror of a better here and now, can help drive home the message of how radically unsustainable our business-as-usual approach has been. Imagining the geographies of lost energy is an endeavour that, rather than highlighting imaginative solutions, seeks to normalise better practices through a critical counter narrative of society observed through the energy lens, thus exposing the under-imagined energy absurdities of extant policies, processes and practices.

As a final point, it is worth noting that such an idea of a counterfactual geographical imagery of the here and now can have relevance beyond energy. For example, issues around food wastage, hunger and obesity could be subject to a similar kind of analysis, helping to challenge complacency, to confront unambitious policies, to motivate citizens and policy makers and identify practicable next steps within our daily lives and local environment on the road to greater sustainability.

\section{Acknowledgements}

I would like to thank Bryn Greer-Wootten and Colin Pooley for their feedback on earlier versions of this paper. The paper has been created in the context of the project: "Energy landscapes: Innovation, development and internationalization of research", acronym ENGELA (Reg. No. ESF OP CZ.1.07/2.3.00/20.0025).

\section{References}

BEGG, K., VAN DER HORST, D. (2004): Preserving environmental integrity in standardised baselines: the role of additionality and uncertainty. Mitigation and Adaptation Strategies for Global Change, Vol. 9, No. 2, p. $181-200$

BOAMAH, F. (2014): Imageries of the contested concepts "land grabbing" and "land transactions": Implications for biofuels investments in Ghana. Geoforum, Vol. 54, p. 324-334.

BURGESS, J., NYE, M. (2008): Re-materialising energy use through transparent monitoring systems. Energy Policy, Vol. 36 , No. 12 , p. $4454-4459$.

CARSON, R. (1962): Silent Spring. New York, Houghton Mifflin, $382 \mathrm{pp}$.

DANIELS, S. (2011): Geographical Imaginations. Transactions of the Institute of British Geographers, Vol. 36, No. 2, p. 182-187.

DE WATERS, J. E., POWERS, S. E. (2011): Energy literacy of secondary students in New York State (USA): A measure of knowledge, affect, and behaviour. Energy Policy, Vol. 39, No. 3, p. 1699-1710.
DAVID, G. D., LAMBERT, D. (2010): Counterfactual geographies: worlds that might have been. Journal of Historical Geography, Vol. 36, No. 3, p. 245-252.

FALL, J. J. (2013): Not a geography of what doesn't exist, but a counter-geography of what does. Rereading Giuseppe Dematteis' Le Metafore della Terra. Progress in Human Geography, Vol. 37, No. 4, p. 542-563.

GREGORY, D., JOHNSTON, R., PRATT, G., WATTS, M. J., WHATMORE, S. [eds.] (2009): The dictionary of human geography. $5^{\text {th }}$ edition. New York, WileyBlackwell, 1072 pp.

HARGREAVES, T., NYE, M., BURGESS, J. (2010): Making energy visible: A qualitative field study of how householders interact with feedback from smart energy monitors. Energy Policy Vol. 38, No. 10, p. 6111-6119.

HARVEY, D. (2000): Spaces of Hope. Ewing, University of California Press, 303 pp.

JACKSON, S., FULLER, D., DUNSFORD, H., MOWBRAY, R., HEXT, S., MACFARLANE R., HAGGETT, C. (2008): Tranquillity Mapping: developing a robust methodology for planning support, Report to the Campaign to Protect Rural England, Centre for Environmental and Spatial Analysis, Northumbria University, Bluespace environments and the University of Newcastle upon on Tyne, 209 pp.

LANCING, D. M. (2010): Carbon's calculatory spaces: the emergence of carbon offsets in Costa Rica. Environment and Planning D: Society and Space, Vol. 28, No. 4, p. $710-725$.

LEVIDOW, L., PAPAIOANNOU, T. (2013): State imaginaries of the public good: shaping UK innovation priorities for bioenergy. Environmental Science \& Policy, Vol. 30, p. 36-49.

NADAI, A., VAN DER HORST, D. (2010a): Introduction: Landscapes of Energy. Landscape Research Vol. 35, No. 2, p. 143-155.

NADAI, A., VAN DER HORST, D. (2010b): Wind power planning, landscapes and publics. Land Use Policy, Vol. 27, No. 2, p. 181-184.

PERREAULT T., VALDIVIA G. (2010): Hydrocarbons, popular protest and national imaginaries: Ecuador and Bolivia in comparative context. Geoforum, Vol. 41, No. 5, p. 689-699.

PIMENTEL, D., PIMENTEL, M. (1979): Food, Energy and Society. London, Edward Arnold, 380 pp.

POOLEY, C. (2010): Landscapes without the car: a counterfactual historical geography of twentieth-century Britain. Journal of Historical Geography, Vol. 36, No. 3, p. $266-275$.

RUSSELL, S. (1993): Writing Energy History: Explaining the Neglect of CHP/DH in Britain. British Journal for the History of Science, Vol. 26, No. 1, p.33-54.

SHIM, D. (2014). Remote sensing place: Satellite images as visual spatial imaginaries. Geoforum, Vol. 51, p. 152-160.

SMIL, V. (1994): Energy in World History. Boulder, Westview Press, 300 pp.

TURNHEIM, B., GEELS, F.W. (2013): The destabilisation of existing regimes; confronting a multi-dimensional framework with a case study of the British coal industry 1913-1967. Research Policy, Vol. 42, No. 10, p. 1749-1767. 
TUCKER, A. (1999): Historical Counterfactuals and Historical Contingency. History and Theory, Vol. 38, No. 2, p. 264-276.

VAN DER HORST, D. (2007). NIMBY or not? Exploring the relevance of location and the politics of voiced opinions in renewable energy siting controversies. Energy Policy, Vol. 35, No. 5, p. 2705-2714.
VERMEYLEN, S., DAVIES, G., VAN DER HORST, D. (2012):

Deconstructing the conservancy map; hxaro, n!ore and rhizomes in the Kalahari. Cartographica, Vol. 46, No. 2, p. 121-134.

WRIGHT, J. K. (1947): Terrae Incognitae: the Place of the Imagination in Geography. Annals of the Association of American Geographers, Vol. 37, No. 1, p. 1-15.

\section{Author's address:}

Dr. Dan VAN DER HORST, Ph.D.

Research Institute of Geography and the Lived Environment

School of GeoSciences, University of Edinburgh

Drummond Street, Edinburgh EH8 9XP, UK

e-mail: Dan.vanderHorst@ed.ac.uk

Initial submission 15 December 2013, final acceptance 5 June 2014

Please cite this article as:

VAN DER HORST, D. (2014): Landscapes of lost energy: Counterfactual geographical imaginary for a more sustainable society. Moravian Geographical Reports, Vol. 22, No. 2, p. 66-72. DOI: 10.2478/mgr-2014-0013. 